\title{
Erratum to: Robust Enhancement of Neural Differentiation from Human ES and iPS Cells Regardless of their Innate Difference in Differentiation Propensity
}

\author{
Dae-Sung Kim • Jae Souk Lee • Joong Woo Leem • Yong Jun Huh • Ji Young Kim • \\ Han-Soo Kim • In-Hyun Park • George Q. Daley • Dong-Youn Hwang • \\ Dong-Wook Kim
}

Published online: 23 April 2010

(C) Springer Science+Business Media, LLC 2010

\section{Erratum to: Stem Cell Rev and Rep \\ DOI 10.1007/s12015-010-9138-1}

In the original publication, the affiliation of authors D.-S. Kim, J. S. Lee, J. W. Leem, Y. J. Huh, J. Y. Kim, D.-W. Kim was incorrectly captured. The authors' correct affiliation should read Department of Physiology, Brain Korea 21 Project for Medical Science, Yonsei University College of Medicine, Seoul 120-752, Korea

The online version of the original article can be found at http://dx.doi. org/10.1007/s12015-010-9138-1.

D.-S. Kim • J. S. Lee ·J. W. Leem • Y. J. Huh • J. Y. Kim •

D.-Y. Hwang $(\varangle)$

D.-W. Kim

Department of Physiology,

Brain Korea 21 Project for Medical Science,

Yonsei University College of Medicine,

Seoul 120-752, Korea

CHA Stem Cell Institute, CHA University College of Medicine, 606-16 Vision bldg., 4th floor, Yeoksam-Dong, Kangnam-Gu, Seoul, Korea

e-mail: hdy@cha.ac.kr

\section{H.-S. Kim}

Department of Laboratory Medicine,

Yonsei University College of Medicine,

Seoul 120-752, Korea

I.-H. Park · G. Q. Daley

Department of Medicine,

Division of Pediatric Hematology Oncology,

Children's Hospital Boston, and Dana-Farber Cancer Institute;

Department of Biological Chemistry and Molecular Pharmacology,

Harvard Medical School,

Karp Family Research Building 7214, 300 Longwood Avenue,

Boston, MA 02115, USA

D.-W. Kim $(\square)$

Department of Physiology, Center for Cell Therapy,

Yonsei University College of Medicine,

134 Shinchon-dong, Seodaemoon-gu,

Seoul, Korea

e-mail: dwkim2@yuhs.ac 